\title{
PERBANDINGAN MODEL SINEKTIK DAN MODEL CONSEPT SENTENCE MODIFICATION DALAM PEMBELAJARAN MENULIS GUGURITAN SISWA KELAS VIII SMP NEGERI I CINEAM KABUPATEN TASIKMALAYA TAHUN AJARAN 2014/2015
}

\author{
Leni Risna Nuraeni, Usep Kuswari \\ SMPN Cineam \\ Pos-el: lenirisna28@yahoo.com
}

\begin{abstract}
Abstrak
Penelitian ini bertujuan untuk menguji efektivitas model Sinektik dan model Consept Sentence Modification dalam meningkatkan kemampuan menulis guguritan Maskumambang siswa kelas VIII SMPN 1 Cineam Kabupaten Tasikmalaya. Penelitian ini menggunakan metode eksperimen yang mencakup desain Randomized Posttest-Only Comparison Group. Sumber data dalam penelitian ini sebanyak 57 siswa yang diambil dari dua kelas, yaitu kelas VIII-A dan VIII-B SMPN 1 Cineam. Hasil pembelajaran menulis guguritan Maskumambang yang menggunakan modél Sinektik rata-ratanya 80. Hasil pembelajaran menulis guguritan Maskumanbang yang menggunakan model Consept Sentence Modification rata-ratanya 78,5. Uji normalitas dengan taraf $99 \%$ menghasilkan data normal dengan perhitungan $\mathrm{x}^{2}{ }_{\text {itung }}<\mathrm{x}_{\text {tabel }}^{2}$ yaitu 7,47 < 11,3. Uji homogenitas antara variansi hasil pembelajaran menulis guguritan Maskumambang yang menggunakan modél Sinektik dan yang menggunakan model Consept Sentence Modification termasuk homogen dengan perhitungan $\mathrm{F}_{\text {itung }}<\mathrm{F}_{\text {tabel }}$ yaitu 1,09 $<1,90$. Dalam taraf kepercayaan 99\% Ha ditolak dalam menulis guguritan Maskumambang yang menggunakan modél Sinektik dan model Consept Sentence Modification dengan perhitungan $\mathrm{t}_{\text {itung }}>\mathrm{t}_{\text {tabél }}$ yaitu 1,830 >1,673. Dengan demikian penelitian ini membuktikan bahwa tidak ada perbedaan yang signifikan antara hasil pembelajaran menulis guguritan Maskumambang yang menggunakan modél Sinektik dan yang menggunakan model Consept Sentence Modification. Meskipun hasil pengolahan data membuktikan bahwa modél Sinektik lebih efektif daripada model Consept Sentence Modification dalam pembelajaran menulis guguritan di kelas VIII SMP Negeri 1 Cineam Kabupaten Tasikmalaya.
\end{abstract}

Kata kunci: model Sinektik, model Consept Sentence Modification, guguritan

\section{THE COMPARISON OF SYNECTIC MODEL AND CONCEPT OF SENTENCE MODIFICATION MODEL IN THE LEARNING OF WRITING GUGURITAN ON EIGHTH GRADE STUDENTS OF SMPN I CINEAM, TASIKMALAYA REGENCY, ACADEMIC YEAR OF 2014/2015}

\begin{abstract}
This study aimed to test the effectiveness of the Synectic model and the Concept of Sentence Modification model in improving the ability of $8^{\text {th }}$ Grade students of SMPN 1 Cineam, Tasikmalaya Regency, in writing Guguritan Maskumambang. This study used an experimental method that involved design Randomized Posttest-Only Comparison Group. The source of data in this study were 57 students of two classes: VIII-A and VIII-B. The learning outcomes of writing Guguritan Maskumambang with the Synectic model are in the average of 80. The learning outcomes of writing Guguritan Maskumambang with the Concept of Sentence Modification model are in the average of 78.5. The normality test with a level of $99 \%$ produced normal data with the calculation $x_{\text {count }}^{2}<x_{\text {tabel, namely }}^{2} 7.47<11.3$. The homogeneity test between the variance of learning outcomes of writing Guguritan
\end{abstract}


Maskumambang with the Synectic model and the Concept of Sentence Modification model is

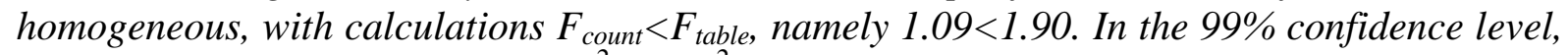

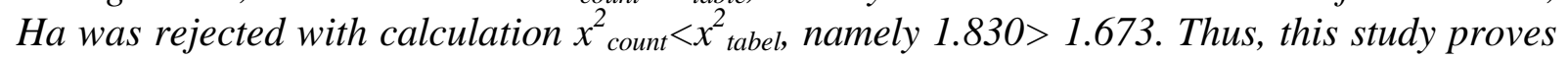
that there is no significant difference between the results of the learning of writing Guguritan Maskumambang by using the Synectic model and Concept of Sentence Modification model. Nevertheless, the data processing proves that the Synectic model is more effective than the Concept of Sentence Modification model in the learning of writing guguritan on $8^{\text {th }}$ grade Students of SMP Negeri 1 Cineam, Tasikmalaya Regency.

Keywords: Synectic model, Concept of Sentence Modification model, guguritan.

\section{PENDAHULUAN}

Menulis merupakan salah satu aspek keterampilan berbahasa, seperti yang dikemukakan oleh Tarigan (2008:1) bahwa keterampilan berbahasa memiliki empat aspek yaitu mendengarkan (listening skills), bercerita (speaking skills), membaca (reading skills), dan menulis (writing skills). Tarigan, (2008:9) menjelaskan bahwa keterampilan menulis merupakan kemampuan menggunakan bahasa secara tertulis untuk menyampaikan informasi suatu peristiwa sehingga timbul komunikasi. Oleh sebab itu, pembelajaran menulis selalu diajarkan baik secara formal maupun non formal.

Rahman (2007:7) menjelaskan bahwa model pembelajaran merupakan pedoman bagi guru dan murid dalam pelaksanaan belajar-mengajar. Tetapi dalam proses pembelajaran, keberhasilan model atau metode yang dipilih oleh guru dalam kegiatan pembelajarannya dipengaruhi oleh beberapa faktor, diantaranya: kemampuan guru dalam mengajar yang berbeda-beda, (2) tujuan yang ingin dicapai terlalu banyak jenisnya, (3) kemampuan murid dalam menerima pengajaran yang berbeda-beda, dan (4) situasi dan kondisi yang tidak menentu. Penggunaan metode atau model pembelajaran dalam proses belajar mengajar sangat berkaitan dengan tercapainya tujuan dan mutu pendidikan.

Salah satu tujuan pembelajaran bahasa Sunda yaitu menciptakan siswa yang kreatif dan terampil dalam menggunakan bahasa Sunda, baik secara lisan maupun dalam bentuk tulisan. Guguritan termasuk karya sastra yang memiliki nilai budaya cukup tinggi, jadi untuk menjaga nilai-nilai tersebut guguritan perlu diajarkan di sekolah. Hal itu juga dibuktikan dengan adanya standar kompetensi dalam SKKD mata pelajaran Bahasa dan Sastra Sunda (2007:96) untuk kelas VIII yang isinya "mampu menulis untuk mengungkapkan pikiran, perasaan, dan keinginan dalam bentuk surat, esei, laporan, sisindiran dan guguritan". Dalam pembelajaran menulis guguritan, guru dituntut untuk kreatif dan terampil dalam menyampaikan materi pembelajaran sebab kenyataannya cara-cara menulis guguritan itu cukup susah dan bukan hal yang mudah bagi siswa.

Saat ini orang yang menulis guguritan semakin jarang. Begitu pula dengan pementasan nya yang sudah jarang dipentaskan. Rusyana (1980:4) menjelaskan bahwa guguritan adalah puisi yang digubah menurut kaidah pupuh. Tidak sedikit siswa yang merasa kesulitan ketika mengungkapkan pikirannya ke dalam bentuk tulisan ditambah dalam menulis guguritan harus dikaitkan dengan kaidah pupuh yang digunakan. Oleh sebab itu, untuk meningkatkan kemampuan siswa dalam menulis guguritan guru harus pintar dalam memilih model pembelajaran yang akan mendukung keberhasilan pembelajarannya.

Model yang dianggap cocok untuk meningkatkan kemampuan siswa dalam menulis puisi hususnya guguritan, diantaranya model Sinektik dan model Consept Sentence Modification. 
Joyce dan Weil (1980:182) menjelaskan bahwa model sinektik merupakan strategi pengajaran yang baik sekali untuk mengembangkan kemampuan kreatif dalam menulis. Dalam proses pembelajaran bahasa, pengembangan dimensi kreativitas sangat penting dan dapat dilaksanakan melalui berbagai kegiatan berbahasa. Kreativitas merupakan hal yang penting dan menjadi salah satu ciri manusia yang berkualitas. Selain itu kreativitas juga yang memungkinkan manusia meningkatkan kualitas hidupnya. Untuk mencapai hal itu, diperlukan sikap dan perilaku kreatif yang harus ditanamkan sejak dini. Perlu diketahui bahwa dasar model sinektik dibentuk melalui empat pandangan yaitu (1) kreativitas merupakan kegiatan sehari-hari, (2) proses kreatif (kreativitas) dapat dipelajari, (3) kreativitas terjadi dimana saja, dan (4) proses penemuan individual akan ditunjang oleh penemuan kelompok.

Aplikasi pembelajaran menulis guguritan dengan model sinektik ini memiliki maksud dan tujuan yakni menggali daya imajinasi dan kreativitas siswa dalam bersastra (menulis guguritan). Hal ini sesuai dengan pendapat Wellek dan Warren (2004: 34) yang menyatakan bahwa sastra adalah sesuatu kegiatan kreatif sebuah karya seni. Dari pernyataan tersebut, sudah semestinya pembelajaran sastra khususnya menulis guguritan di kelas ditujukan pada arah pengembangan proses kreativitas siswa dalam seni bersastra oleh guru. Sudah semestinya pula pembelajaran sastra diarahkan untuk memupuk minat siswa terhadap sastra sehingga siswa akan tertarik dengan pembelajaran sastra yakni menulis guguritan.

Selain model Sinektik, model pembelajaran yang mampu merangsang kreativitas siswa dalam mengembangkan kompetensi menulis puisi adalah model Consept Sentence Modification. Model pembelajaran ini merupakan modifikasi dari model pembelajaran Concept Sentence. Dalam proses pembelajaran dengan model
Consept Sentence Modification, siswa akan belajar bersama, berdisukusi, dan menentukan kata-kata kunci yang berhubungan objek penulisan puisi. Dengan model pembelajaran ini akan tercipta suasana pembelajaran yang lebih menyenangkan, komunikatif, dan kondusif. Siswa menjadi lebih aktif, perhatian lebih terarah serta lebih antusias dan tidak merasa bosan.

Siswa yang selama ini merasa kesulitan untuk menentukan diksi (pilihan kata) menjadi lebih mudah karena dapat menggunakan kata-kata kunci yang dapat memancing daya imajinasi siswa dalam menulis puisi. Model pembelajaran Consept Sentence Modification merupakan teknik pembelajaran yang dapat membantu siswa dalam menulis guguritan. Dengan teknik ini siswa yang merasa kesulitan dalam menentukan kalimat dapat membuatnya dengan mengembangkan kata kunci yang telah dibuat bersama. Siswa akan menjadi lebih antusias dan bersemangat dalam mengikuti pembelajaran menulis guguritan. Dengan model pembelajaran ini siswa merasa bergairah dan lebih tertarik untuk mengikuti pembelajaran bahasa Sunda terutama menulis guguritan maskumambang.

Kaidah pupuh maskumambang dipilih dalam penelitian ini karena jumlah baitnya yang sedikit (4 baris, dengan patokan 12i6a-8i-8a) dan siswa paling memahami pupuh ini baik dalam patokan maupun watak pupuh dibandingkan dengan pupuhpupuh yang lainnya. Jadi permasalahan yang ditinjau adalah perbandingan antara model sinektik dan model consept sentence modification.

\section{METODE}

Metode penelitian yang digunakan dalam penelitian ini adalah eksperimen. Penelitian eksperimen merupakan penelitian kuantitatif yang memenuhi semua persyaratan untuk menguji hubungan sebab akibat. Sugiono (2013:72) menjelaskan 
bahwa dalam penelitian eksperimen ada perlakuan (treatment). Syaodih (2005:194) menjelaskan bahwa penelitian eksperimen merupakan pendekatan penelitian yang khas, karena penelitian eksperimen menguji secara langsung pengaruh suatu variabel terhadap variabel lain, dan menguji hipotesis hubungan sebab akibat.

Dalam penelitian ini metode ini membandingkan antara pengaruh model sinektik dan model consept sentence modification dalam meningkatkan pembelajaran menulis guguritan. Oleh sebab itu, penelitian ini menggunakan "Randomized Posttest-Only Comparison Group Desain". Desain eksperimen ini sama dengan desain eksperimen kelompok pembanding pretest-posttest beracak tetapi desain tersebut tidak menggunakan test awal. Supaya lebih jelas dapat digambarkan sebagai berikut:

\section{Tabel 1: Metode Penelitian}

\begin{tabular}{ccc}
\hline Kelompok & Perlakuan & Posttest \\
\hline X-1 & $\mathrm{A}$ & $\mathrm{O}_{1}$ \\
X-2 & $\mathrm{B}$ & $\mathrm{O}_{2}$ \\
\hline
\end{tabular}

\section{Keterangan:}

$\mathrm{X}-1=$ Kelas VIII-A

$\mathrm{X}-2=$ Kelas VIII-B

$\mathrm{A}=$ Perlakuan yang menggunakan model Sinektik

$\mathrm{B}=$ Perlakuan yang menggunakan model Consept Sentence Modification

$\mathrm{O}=$ Hasil observasi setelah perlakuan

Sumber data penelitian ini mencakup populasi dan sampel. Arikunto (2009:172) menjelaskan bahwa populasi adalah keseluruhan subjek penelitian. Yang menjadi populasi dalam penelitian ini adalah siswa kelas VIII SMP Negeri I Cineam Tahun Ajaran 2014/2015 yang beralamat di Jl. Asrama No. 14 Desa Cineam Kecamatan Cineam Kabupaten Tasikmalaya. Sedangkan sampel adalah wakil atau sebagian dari populasi yang diteliti (Arikunto, 2009:174). Teknik random sampling digunakan dalam menentukan sampel yang akan diteliti. Random sampling yang digunakan dalam penelitian ini adalah simple random sampling. Semua kelas memiliki kesempatan yang sama untuk dijadikan kelas sampel, oleh sebab itu karakteristik populasi diasumsikan sama (RPP, silabus, buku sumber,dsb). Untuk menentukan kelas sampel, dalam penelitian ini digunakan sampling undian dan yang diundinya adalah kelas. Setelah diundi kelas VIII-A (27 siswa) merupakan kelas sampel yang menggunakan model Sinektik dan kelas VIII-B (30 siswa) merupakan kelas sampel yang menggunakan model Consept Sentence Modification.

Instrumen yang digunakan dalam penelitian ini adalah tes tertulis yang berupa perintah. Tes yang digunakan dalam penelitian ini adalah tes mengukur kemampuan siswa dalam menulis guguritan Maskumambang yang menggunakan model Sinektik dan yang menggunakan model Consept Sentence Modification. Supaya lebih jelas dapat di lihat di bawah ini: 


\section{Tés Nulis Guguritan \\ SMP Negeri I Cineam \\ Taun Ajaran 2014/2015}

Pék jieun guguritan panjangna minimal 3 pada, témana bébas, patokan nu digunakeuna pupuh Maskumambang!

Tes juga digunakan untuk mengumpulkan data hasil belajar menulis guguritan Maskumambang yang dilaksanakan oleh siswa kelas VIII-A yang belajar menulis guguritan Maskumambang dengan menggunakan model Sinektik, dan siswa kelas VIII-B yang belajar menulis guguritan Maskumambang dengan menggunakan model Consept Sentence Modification. Ketentuan yang digunakan dalam tes menulis guguritan adalah (1) guguritan minimal tiga bait, (2) tema bebas, (3) kriteria yang dinilai mencakup ejahan, pilihan kecap jeung gaya basa, tulisan, hubungan antar baris dan antar bait, guru lagu, guru wilangan, jumlah baris dalam tiap bait, dan watak pupuh maskumambang, dan (4) waktu yang disediakan 60 menit.

Setelah data terkumpul langsung diolah dan dianalisis sehingga dapat diketahui hasil dan kesimpulannya. Langkah-langkah dalam mengolah data adalah: (1) memeriksa hasil belajar nulis guguritan siswa dan memberi tanda pada bagian yang salah, (2) memberikan nilai, (3) memasukan nilai pada tabel yang telah disediakan, dan (4) mengolah data melalui (a) uji sipat data (uji normalitas dan uji homogenitas), dan (b) uji hipotesis.

\section{HASIL DAN PEMBAHASAN}

Hasil penelitian ini mencakup (1) hasil belajar menulis guguritan Maskumambang yang menggunakan model Sinektik, (2) hasil belajar menulis guguritan Maskumambang yang menggunakan model Consept Sentence Modification, dan (3) perbedaan hasil belajar menulis guguritan maskumambang yang menggunakan model Sinektik dan model Consept Sentence Modification.

\section{Hasil belajar menulis guguritan Maskumambang yang menggunakan model Sinektik}

Hasil belajar menulis guguritan maskumambang yang menggunakan model Sinektik dari 30 siswa, 18 siswa memiliki kemampuan menulis yang sangat baik, 6 siswa memiliki kemampuan menulis yang baik, dan 6 siswa memiliki kemampuan menulis sedang. Setelah diakumulasikan hasil belajar menulis guguritan Maskumambang yang menggunakan model Sinektik memiliki rata-rata nilai 80. Hasil belajar menulis guguritan Maskumambang yang menggunakan model Sinektik dilihat dari ejahannya baik dan rata-ratanya 81,5. Dilihat dari diksi dan gaya bahasanya sedang, rata-ratanya 78 . Dilihat dari hubungan isi dan judul baik, rata-ratanya 81,7. Dilihat dari kerapihan tulisannya sedang, rata-ratanya 78,8. Dilihat dari hubungan antar bait dan antar baris dalam tiap bait baik, rata-ratanya 82 . Dilihat dari aturan atau kaidah pupuh yang digunakan sedang, rata-ratanya 78. Supaya lebih jelas dapat dilihat pada tabel di bawah ini:

Tabel 2: Hasil belajar menulis guguritan Maskumambang yang menggunakan model Sinektik

\begin{tabular}{|c|c|c|c|c|c|c|c|c|c|c|}
\hline \multirow{2}{*}{ No. } & \multirow{2}{*}{$\begin{array}{l}\text { No. } \\
\text { Kode }\end{array}$} & \multicolumn{6}{|c|}{ Skor } & \multirow{2}{*}{$\Sigma$} & \multirow{2}{*}{$\begin{array}{l}\text { Skor } \\
\text { ahir }\end{array}$} & \multirow{2}{*}{$\begin{array}{c}\text { Tingkat } \\
\text { kamampuh }\end{array}$} \\
\hline & & $\mathbf{A}$ & B & $\mathbf{C}$ & D & $\mathbf{E}$ & $\mathbf{F}$ & & & \\
\hline 1 & S1 & 80 & 80 & 90 & 90 & 80 & 80 & 500 & 83.3 & Baik \\
\hline 2 & S2 & 80 & 80 & 80 & 80 & 90 & 90 & 500 & 83.3 & Baik \\
\hline 3 & S3 & 90 & 90 & 80 & 80 & 80 & 80 & 500 & 83.3 & Baik \\
\hline
\end{tabular}




\begin{tabular}{|c|c|c|c|c|c|c|c|c|c|c|}
\hline \multirow{2}{*}{ No. } & \multirow{2}{*}{$\begin{array}{c}\text { No. } \\
\text { Kode }\end{array}$} & \multicolumn{6}{|c|}{ Skor } & \multirow{2}{*}{$\sum$} & \multirow{2}{*}{$\begin{array}{l}\text { Skor } \\
\text { ahir }\end{array}$} & \multirow{2}{*}{$\begin{array}{c}\text { Tingkat } \\
\text { kamampuh }\end{array}$} \\
\hline & & $\mathbf{A}$ & B & $\mathbf{C}$ & D & $\mathbf{E}$ & $\mathbf{F}$ & & & \\
\hline 4 & S4 & 80 & 70 & 80 & 80 & 80 & 80 & 470 & 78.3 & Sedang \\
\hline 5 & S5 & 90 & 80 & 90 & 80 & 80 & 80 & 500 & 83.3 & Baik \\
\hline 6 & S6 & 80 & 70 & 80 & 80 & 90 & 90 & 490 & 81.7 & Sangat baik \\
\hline 7 & S7 & 90 & 80 & 90 & 90 & 90 & 90 & 530 & 88.3 & Baik \\
\hline 8 & S8 & 80 & 80 & 80 & 90 & 90 & 90 & 510 & 85 & Baik \\
\hline 9 & S9 & 90 & 80 & 90 & 90 & 90 & 90 & 530 & 88.3 & Baik \\
\hline 10 & $\mathrm{~S} 10$ & 90 & 80 & 80 & 80 & 90 & 80 & 500 & 83.3 & Baik \\
\hline 11 & S11 & 70 & 70 & 80 & 70 & 80 & 70 & 440 & 73.3 & Sedang \\
\hline 12 & S12 & 80 & 80 & 90 & 80 & 90 & 80 & 500 & 83.3 & Baik \\
\hline 13 & S13 & 80 & 80 & 80 & 80 & 90 & 80 & 490 & 81.7 & Baik \\
\hline 14 & S14 & 90 & 80 & 80 & 80 & 80 & 70 & 480 & 80 & Baik \\
\hline 15 & S15 & 80 & 70 & 80 & 80 & 80 & 80 & 470 & 78.3 & Sedang \\
\hline 16 & S16 & 70 & 70 & 70 & 60 & 60 & 70 & 400 & 66.7 & Kurang \\
\hline 17 & S17 & 90 & 80 & 90 & 80 & 90 & 80 & 510 & 85 & Baik \\
\hline 18 & S18 & 80 & 80 & 80 & 70 & 80 & 70 & 460 & 76.7 & Sedang \\
\hline 19 & S19 & 90 & 80 & 80 & 80 & 90 & 80 & 500 & 83.3 & Baik \\
\hline 20 & S20 & 70 & 80 & 70 & 60 & 70 & 60 & 410 & 68.3 & Kurang \\
\hline 21 & S21 & 90 & 90 & 90 & 80 & 90 & 90 & 530 & 88.3 & Baik \\
\hline 22 & S22 & 80 & 80 & 90 & 80 & 80 & 80 & 490 & 81.7 & Baik \\
\hline 23 & S23 & 70 & 70 & 80 & 80 & 70 & 60 & 430 & 71.7 & Sedang \\
\hline 24 & S24 & 70 & 70 & 70 & 80 & 70 & 70 & 430 & 71.7 & Sedang \\
\hline 25 & S25 & 90 & 80 & 90 & 70 & 90 & 80 & 500 & 83.3 & Baik \\
\hline 26 & S26 & 80 & 80 & 80 & 80 & 80 & 70 & 470 & 78.3 & Sedang \\
\hline 27 & S27 & 80 & 70 & 80 & 70 & 80 & 70 & 450 & 75 & Sedang \\
\hline 28 & S28 & 70 & 70 & 70 & 70 & 70 & 70 & 420 & 70 & Sedang \\
\hline 29 & S29 & 85 & 90 & 70 & 85 & 80 & 80 & 490 & 81.7 & Baik \\
\hline 30 & $\mathrm{~S} 30$ & 80 & 80 & 90 & 90 & 80 & 80 & 500 & 83.3 & Baik \\
\hline & $\sum$ & 2445 & 2340 & 2450 & 2365 & 2460 & 2340 & 14400 & 2627.7 & \\
\hline & a-rata & 81.5 & 78 & 81.7 & 78.8 & 82 & 78 & 80 & 80 & \\
\hline
\end{tabular}

\section{Keterangan:}

$\mathrm{A}=$ ejahan

$\mathrm{B}=$ ketepatan dalam memilih diksi dan gaya bahasa

$\mathrm{C}=$ kemampuan menghubungkan isi dan judul

$\mathrm{D}=$ kerapihan tulisan

$\mathrm{E}=$ kemampuan menghubungkan antar bait dan antar baris pada tiap bait

$\mathrm{F}$ = mampu memenuhi kaidah pupuh

*tingkat kamampuh: $\quad 90-100=$ sangat baik

$80-89=$ baik

$70-79=$ sedang

$60-69=$ kurang

$50-59=$ kurang sekali

\section{Hasil belajar menulis guguritan} Maskumambang yang menggunakan model Consept Sentence Modification

Hasil belajar menulis guguritan maskumambang yang menggunakan model Consept Sentence Modification dari 27 siswa, 7 siswa memiliki kemampuan menulis yang sangat baik, 4 siswa memiliki kemampuan menulis yang baik, 11 siswa memiliki kemampuan menulis sedang, dan
5 siswa kemampuan menulisnnya masih kurang. Setelah diakumulasikan hasil belajar menulis guguritan maskumambang yang menggunakan model Consept Sentence Modification memiliki rata-rata nilai 78,5. Hasil belajar menulis guguritan maskumambang yang menggunakan model Sinektik dilihat dari ejahannya baik dan rata-ratanya 80,6. Dilihat dari diksi dan gaya bahasanya sedang, rata-ratanya 76,7 . 
Dilihat dari hubungan isi dan judul baik, rata-ratanya 80,7. Dilihat dari kerapihan tulisannya sedang, rata-ratanya 76,8. Dilihat dari hubungan antar bait dan antar baris dalam tiap bait baik, rata-ratanya 81,1 .
Dilihat dari aturan atau kaidah pupuh yang digunakan sedang, rata-ratanya 75,6. Supaya lebih jelas dapat dilihat pada tabel di bawah ini.

Tabel 3: Hasil belajar menulis guguritan Maskumambang yang menggunakan model Consept Sentence Modification

\begin{tabular}{|c|c|c|c|c|c|c|c|c|c|c|}
\hline \multirow{3}{*}{ No. } & \multirow{3}{*}{$\begin{array}{l}\text { No. } \\
\text { Kode }\end{array}$} & \multirow{2}{*}{\multicolumn{8}{|c|}{ Skor }} & \multirow{3}{*}{$\begin{array}{c}\text { Tingkat } \\
\text { kamampuh }\end{array}$} \\
\hline & & \multicolumn{5}{|c|}{ Skor } & & \multirow{2}{*}{$\sum$} & \multirow{2}{*}{ Skor ahir } & \\
\hline & & $\mathbf{A}$ & B & $\mathbf{C}$ & D & $\mathbf{E}$ & $\mathbf{F}$ & & & \\
\hline 1 & S1 & 90 & 80 & 90 & 90 & 90 & 90 & 530 & 88.3 & Sedang \\
\hline 2 & $\mathrm{~S} 2$ & 90 & 80 & 80 & 80 & 90 & 80 & 500 & 83.3 & Sedang \\
\hline 3 & S3 & 70 & 70 & 80 & 70 & 80 & 70 & 440 & 73.3 & Sedang \\
\hline 4 & $\mathrm{~S} 4$ & 80 & 80 & 90 & 80 & 90 & 80 & 500 & 83.3 & Baik \\
\hline 5 & S5 & 80 & 80 & 80 & 80 & 90 & 80 & 490 & 81.7 & Sangat baik \\
\hline 6 & S6 & 90 & 80 & 80 & 80 & 80 & 70 & 480 & 80 & Kurang \\
\hline 7 & S7 & 80 & 70 & 80 & 80 & 80 & 80 & 470 & 78.3 & Baik \\
\hline 8 & S8 & 70 & 70 & 70 & 60 & 60 & 70 & 400 & 66.7 & Kurang \\
\hline 9 & S9 & 90 & 80 & 90 & 80 & 90 & 80 & 510 & 85 & Sangat baik \\
\hline 10 & S10 & 80 & 80 & 80 & 70 & 80 & 70 & 460 & 76.7 & Sangat baik \\
\hline 11 & S11 & 90 & 80 & 80 & 80 & 90 & 80 & 500 & 83.3 & Sedang \\
\hline 12 & S12 & 70 & 80 & 70 & 60 & 70 & 60 & 410 & 68.3 & Sangat baik \\
\hline 13 & S13 & 90 & 90 & 90 & 80 & 90 & 90 & 530 & 88.3 & Sangat baik \\
\hline 14 & S14 & 80 & 80 & 90 & 80 & 80 & 80 & 490 & 81.7 & Sedang \\
\hline 15 & S15 & 70 & 70 & 80 & 80 & 70 & 60 & 430 & 71.7 & Sedang \\
\hline 16 & S16 & 70 & 70 & 70 & 80 & 70 & 70 & 430 & 71.7 & Baik \\
\hline 17 & S17 & 90 & 80 & 90 & 70 & 90 & 80 & 500 & 83.3 & Kurang \\
\hline 18 & S18 & 80 & 80 & 80 & 80 & 80 & 70 & 470 & 78.3 & Sedang \\
\hline 19 & S19 & 80 & 70 & 80 & 70 & 80 & 70 & 450 & 75 & Sedang \\
\hline 20 & S20 & 70 & 70 & 70 & 70 & 70 & 70 & 420 & 70 & Sedang \\
\hline 21 & S21 & 85 & 90 & 70 & 85 & 80 & 80 & 490 & 81.7 & Kurang \\
\hline 22 & S22 & 80 & 70 & 80 & 80 & 80 & 80 & 470 & 78.3 & Baik \\
\hline 23 & $\mathrm{~S} 23$ & 70 & 70 & 70 & 80 & 80 & 70 & 440 & 73.3 & Kurang \\
\hline 24 & S24 & 70 & 70 & 80 & 70 & 70 & 70 & 430 & 71.7 & Sedang \\
\hline 25 & S25 & 90 & 80 & 90 & 70 & 90 & 70 & 490 & 81.7 & Sangat baik \\
\hline 26 & S26 & 90 & 80 & 90 & 90 & 80 & 90 & 520 & 86.7 & Sedang \\
\hline 27 & S27 & 80 & 70 & 80 & 80 & 90 & 80 & 480 & 80 & Sangat baik \\
\hline & $\sum$ & 2175 & 2070 & 2180 & 2075 & 2190 & 2040 & 12730 & 2070.2 & \\
\hline & -rata & 80.6 & 76.7 & 80.7 & 76.8 & 81.1 & 75.6 & 78.5 & 78.5 & \\
\hline
\end{tabular}

Keterangan:

$\mathrm{A}=$ ejahan

$\mathrm{B}=$ ketepatan dalam memilih diksi dan gaya bahasa

$\mathrm{C}$ =kemampuan menghubungkan isi dan judul

$\mathrm{D}=$ kerapihan tulisan

$\mathrm{E}=$ kemampuan menghubungkan antar bait dan antar baris pada tiap bait

$\mathrm{F}=$ mampu memenuhi kaidah pupuh

$\begin{array}{lll}* \text { tingkat kamampuh: } & 90-100=\text { sangat baik } & 70-79=\text { sedang } \\ 80-89=\text { baik } & 60-69=\text { kurang }\end{array} \quad 50-59=$ kurang sekali

$$
80-89=\text { baik } \quad 60-69=\text { kurang }
$$

Perbedaan hasil belajar menulis guguritan maskumambang yang menggunakan model Sinektik dan model Consept Sentence Modification

Berdasarkan hasil di atas, terlihat hasil belajar menulis guguritan maskumambang yang menggunakan model Sinektik lebih tinggi daripada hasil belajar menulis guguritan maskumambang yang menggunakan model Consept Sentence Modification. Supaya lebih jelas lihatlah beberapa contoh hasil belajar menulis 
guguritan maskumambang dari tiap aspek yang dinilai di bawah ini.

1) Kemampuan memakai ejahan

Dilihat dari aspek ejahan, hasil belajar siswa yang menulis guguritan maskumambang dengan menggunakan model Sinektik kemampuannya baik sebab rata-rata nilainya adalah 81,5. Tapi walaupun demikian masih ada siswa yang belum mampu menulis ejahan dengan tepat, seperti di bawah ini.

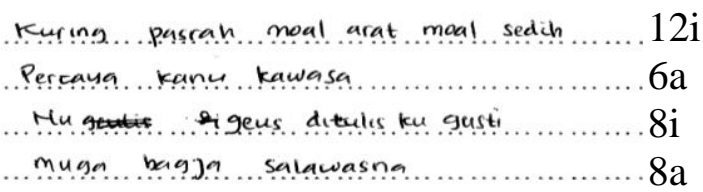

Dalam tulisan di atas terlihat ada kata yang salah dalam ejahannya. Kata "gusti" seharusnya hurup 'G'nya besar, sebab kata "Gusti" merupakan salah satu kata ganti atau panggilan kepada Tuhan YME.

Hasil belajar siswa yang menulis guguritan maskumambang dengan menggunakan model Consept Sentence Modification juga memiliki kemampuan yang baik sebab rata-rata nilainya tidak jauh berbeda yaitu 80,6. Adapun contoh hasil tulisannya seperti di bawah ini.

Kuncoon hirup kuring sangsara teuing 1

beda jeung Anjeunna .................. 6

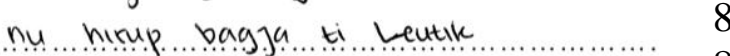

sadayana kacumponan 8a

Dalam tulisan di atas terlihat ada dua kata yang salah dalam ejahannya, yaitu kata "Anjeunna" dan "Leutik". Kata "Anjeunna" dan "Leutik" seharusnya huruf awalnya ditulis memakai huruf kecil sebab berada diujung kalimah. Selain itu kecap "Anjeunna" bisa menggunakan huruf "A" besar kalau "Anjeunna" disana sebagai kata ganti untuk Tuhan YME, sedangkan disana bukan untuk Tuhan YME melainkan untuk sahabatnya. Jadi penulisan seperti itu dianggap tidak tepat.
Dengan demikian, hasil menulis guguritan maskumambang baik yang menggunakan model Sinektik maupun yang menggunakan model Consept Sentence Modification kemampuannya sudah baik meskipun masih ada siswa yang kurang tepat menggunakan ejahan dalam tulisannya.

2) Kemampuan dalam memilih kata dan gaya bahasa

Dilihat dari pemilihan kata dan gaya basa, hasil belajar siswa yang menulis guguritan maskumambang dengan menggunakan model Sinektik dan yang menggunakan model Consept Sentence Modification kemampuannya masih sedang. Sebab setelah dianalisis dan dihitung, hasil belajar siswa yang menulis guguritan maskumambang dengan menggunakan model Sinektik rata-ratanya adalah 78 dan yang menggunakan model Consept Sentence Modification rata-ratanya adalah $76,7$.

Guguritan termasuk salah satu jenis puisi. Oleh karena itu dalam menulis guguritan, penulis harus pintar dalam memilih kata maupun gaya bahasa karena puisi maupun guguritan akan terlihat indah dan bagus apabila menggunakan kata-kata yang tepat apalagi kata-kata yang berupa kiasan atau kata-kata yang memiliki makna konotatif yang membuat pembaca penasaran. Tapi hal tersebutlah yang mengakibatkan para siswa merasa sulit untuk memilih dan menentukan kata maupun gaya bahasa yang cocok dalam tulisannya. Selain itu dikarenakan guguritan ditulis dalam bahasa sunda Seperti contoh di bawah ini.

Contoh hasil karangan guguritan maskumambang yang menggunakan model Sinektik:

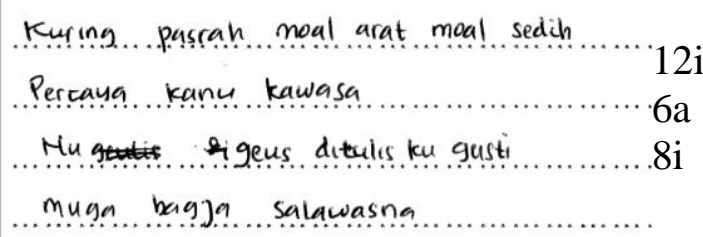


Guguritan di atas dalam aspek pemilihan katanya kurang tepat, sebab ada dua kata yang menggunakan bahasa Indonesia yaitu "Sedih" dan "Kuasa". Hal tersebut dikarenakan kurangnya pemahaman siswa terhadap kosakata bahasa Sunda apalagi kata-kata yang biasa digunakan dalam karya sastra. Pembelajaran menulis guguritan maskumambang ini adalah bagian dari pembelajaran bahasa Sunda oleh sebab itu guguritan ini harus menggunakan bahasa Sunda.

Contoh hasil karangan guguritan maskumambang yang menggunakan model Consept Sentence Modification:

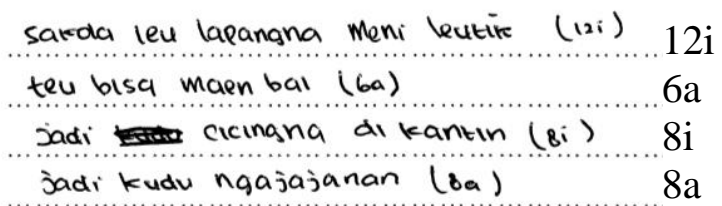

Guguritan diatas hampir semuanya menggunakan bahasa Sunda. Tapi jika dilihat dari bidang sastra terutama guguritan, kata-kata yang semuanya memiliki arti yang sebenarnya kurang tepat jika digunakan dalam karya sastra terutama guguritan. Sedangkan baik puisi, guguritan, ataupun sajak akan lebih bagus dan lebih indah apabila dalam tulisannya menggunakan kata-kata yang indah apalagi yang memiliki arti tidak sebenarnya (konotatif).

3) Kemampuan menghubungkan isi guguritan dengan judul

Dilihat kemampuan menghubungkan isi guguritan dengan judul, hasil belajar siswa yang menulis guguritan maskumambang dengan menggunakan model Sinektik dan yang menggunakan model Consept Sentence Modification kemampuannya sudah baik. Sebab setelah dianalisis dan dihitung, hasil belajar siswa yang menulis guguritan maskumambang dengan menggunakan model Sinektik rataratanya adalah 81,7 dan yang menggunakan model Consept Sentence Modification rata- ratanya adalah 80,7. Tapi walaupun demikian masih banyak siswa yang terkendala dalam memberikan judul karangannya. Seperti contoh di bawah ini:

Contoh hasil karangan guguritan maskumambang yang menggunakan model Sinektik:

Judul: Kanyaah (Kasih Sayang)

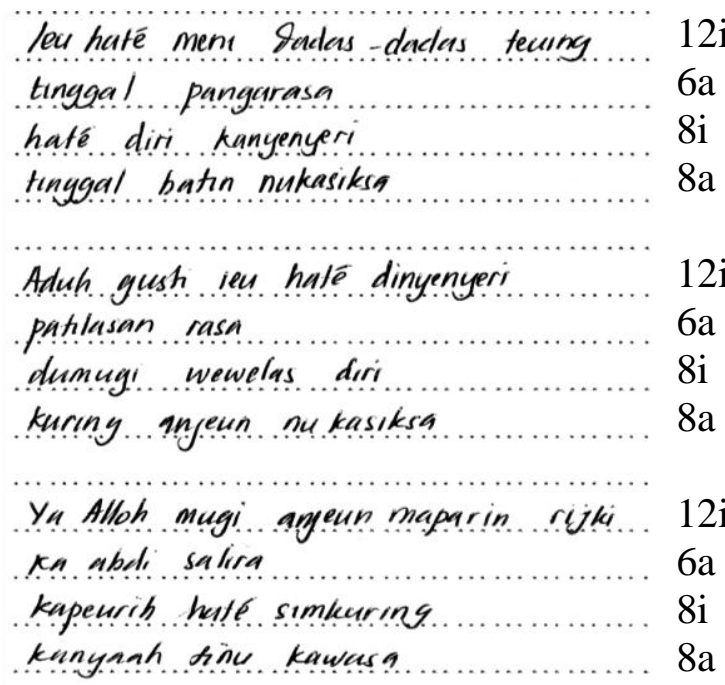

Guguritan di atas menggambarkan hubungan keterkaitan antara judul dan isi. Judul guguritannya adalah Kanyaah (kasih sayang) tetapi dilihat dari isinya malah memperlihatkan kesengsaraan, sedih dan sakit hati. Padahal apabila judulnya Kanyaah (kasih sayang), isinya juga harus menggambarkan kasih sayang, kebahagiaan, saling mencintai, bukan malah sebaliknya yang menggambarkan penderitaan.

Disisi lain aspek ini merupakan aspek termudah, akan tetapi masih banyak siswa yang kebingungan ketika akan memberi judul karangan yang ditulisnya. Akhirnya banyak siswa yang tidak memberikan judul terhadap tulisannya. Seperti hasil karangan guguritan maskumambang yang menggunakan model Consept Sentence Modification di bawah ini. 


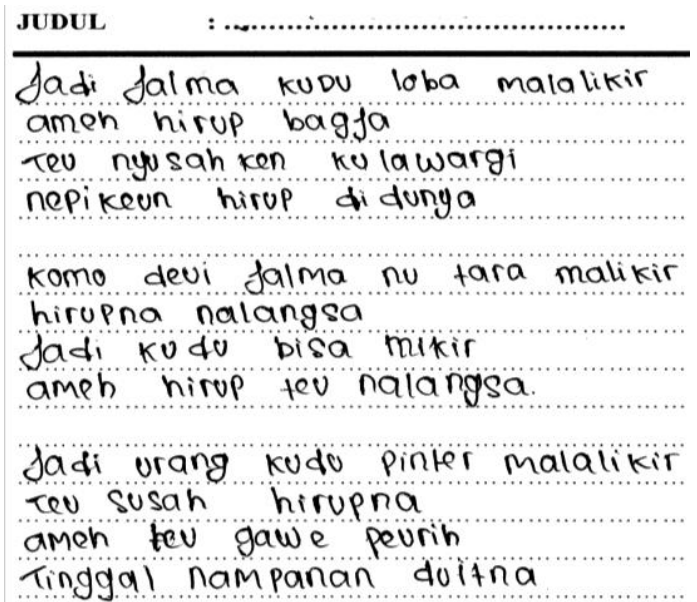

Guguritan di atas tidak diberi judul sama sekali dikarenakan siswa merasa bingung dalam memberikan judul karangannya. Ahirnya lebih baik tidak memakai judul daripada memberikan judul yang salah.

\section{4) Kerapihan tulisan}

Dalam aspek ini yang dinilai adalah kerapihan tulisan. Tulisan sangat mempengaruhi pembaca dalam menafsirkan isi bacaan sebab apabila tulisannya tidak jelas atau tidak dimengerti oleh yang membaca akan menimbulkan tafsiran yang berbeda yang akan mengakibatkan tujuan yang ingin disampaikanoleh penulis tidak sampai kepada pembaca.

Hasil belajar siswa yang menulis guguritan maskumambang dengan menggunakan model Sinektik dan yang menggunakan model Consept Sentence Modification kemampuannya masih sedang. Sebab setelah dianalisis dan dihitung, hasil belajar siswa yang menulis guguritan maskumambang dengan menggunakan model Sinektik rata-ratanya adalah 78,8 dan yang menggunakan model Consept Sentence Modification rata-ratanya adalah 76,8 .

Contoh tulisan siswa yang menggunakan model Sinektik:

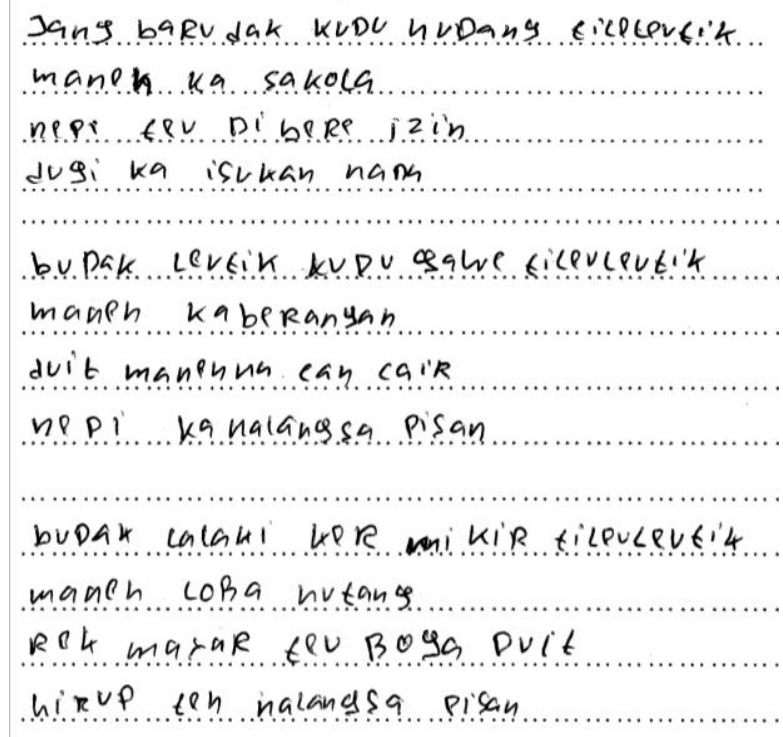

Contoh tulisan siswa yang menggunakan model Consept Sentence Modification:

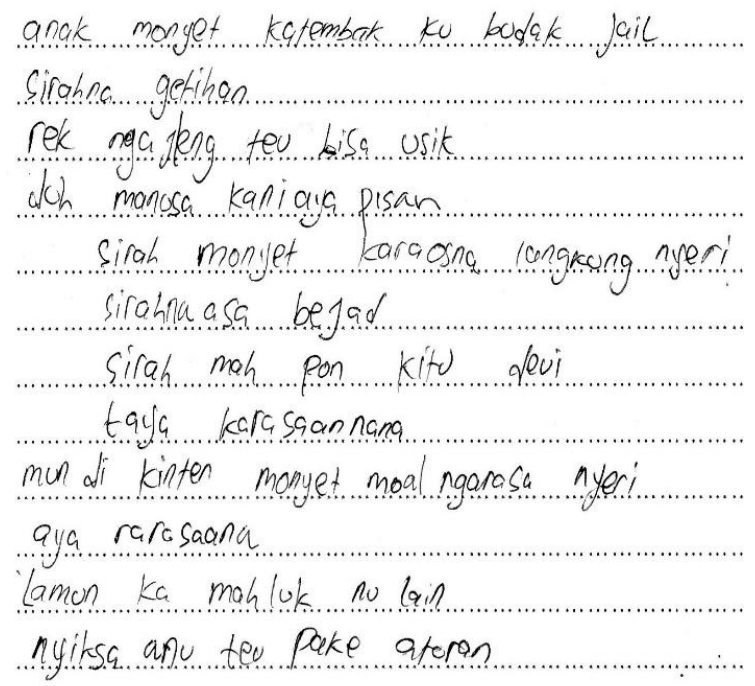

Kemampuan menghubungkan antar bait dan antar padalisan tiap bait

Dalam aspek ini, hasil belajar siswa yang menulis guguritan maskumambang dengan menggunakan model Sinektik dan yang menggunakan model Consept Sentence Modification kemampuannya sudah baik. Sebab setelah dianalisis dan dihitung, hasil belajar siswa yang menulis guguritan maskumambang dengan menggunakan model Sinektik rata-ratanya adalah 82 dan yang menggunakan model Consept Sentence Modification rata-ratanya adalah 81,1. 
Dari penilaian yang dihasilkan aspek ini merupakan aspek yang memiliki ratarata nilai tertinggi diantara aspek yang lainnya, baik siswa yang menulis guguritan maskumambang dengan menggunakan model Sinektik maupun siswa yang menggunakan model Consept Sentence Modification. Supaya lebih jelas dapat dilihat dalam contoh guguritan di bawah ini.

Contoh tulisan siswa yang menggunakan model Sinektik:
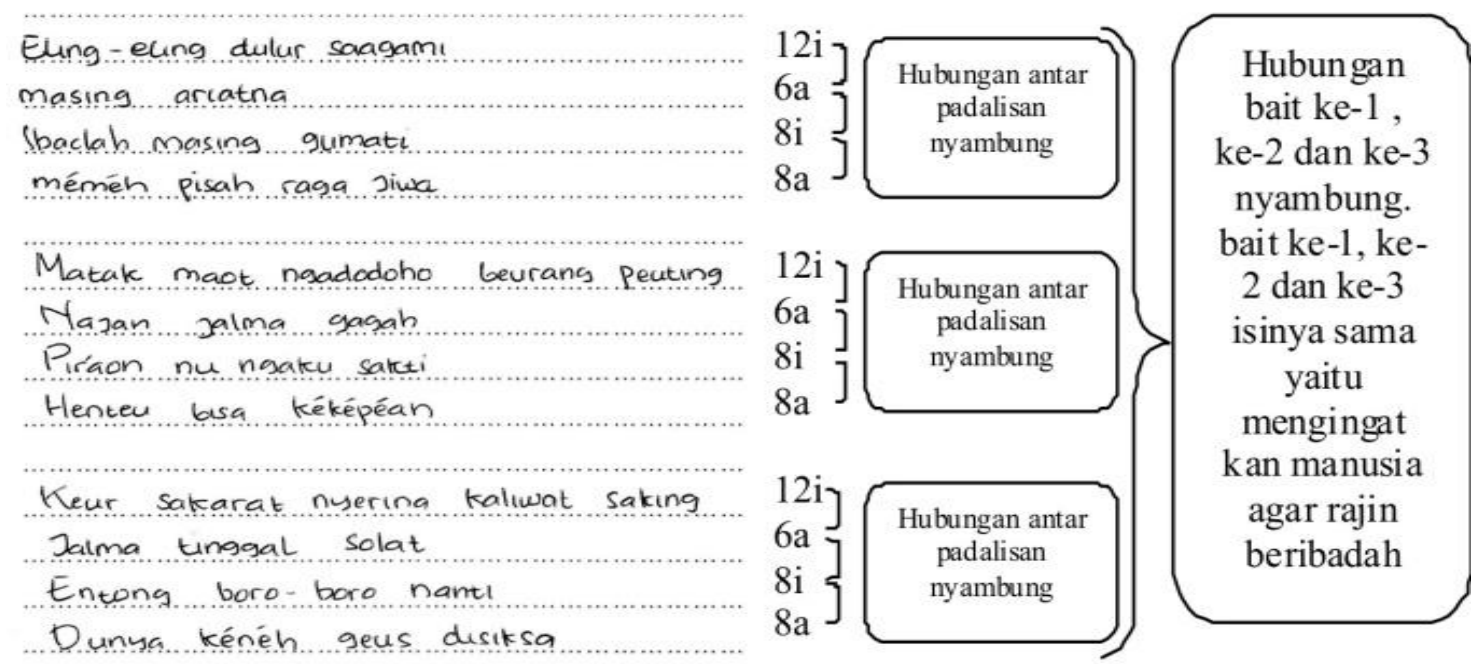

Contoh tulisan siswa yang menggunakan model Consept Sentence Modification:

Jadi Jalma kudu loba malalikir
amen hirup bagja
reu nyusah ken ku lawargi
nepikeun hirup di dunga
komo devi Jalma nu tara malikir
hirupna nalangsa
Jadi ku du bisa mikir
amph hirop teu nalangsa.
Jadi urang kudo pinter malalikir
reu susah hirupna
ameh keu gawe peurih
Tinggal nampanan doitra

5) Kemampuan menggunakan kaidah pupuh

Kaidah pupuh yang dinilai dalam aspek ini adalah guru lagu, guru wilangan, jumlah baris dalam tiap bait dan watak pupuh. Aspek ini dianggap aspek paling susah dibanding aspek yang lainnya sebab aspek ini sangat mempengaruhi benar tidak nya siswa dalam menulis guguritan.
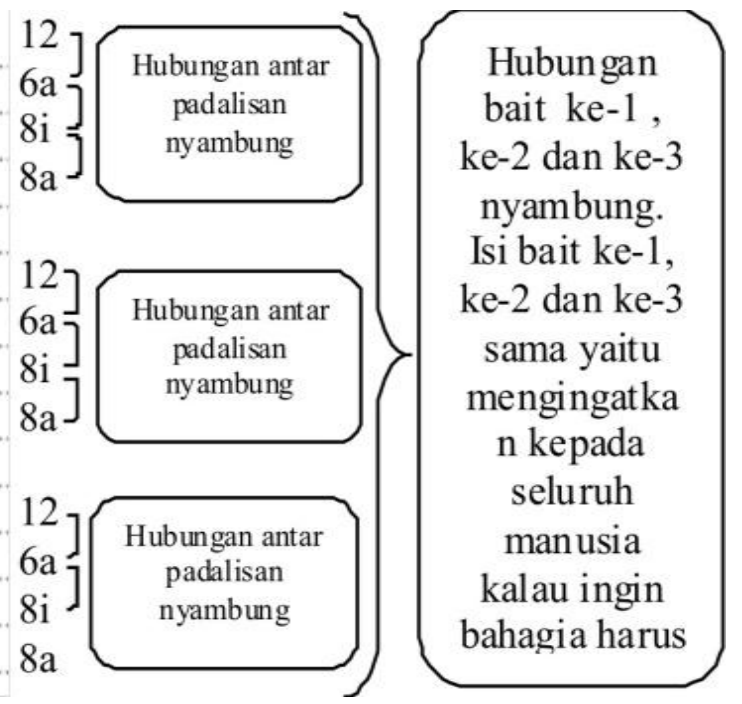

Hasil belajar siswa yang menulis guguritan maskumambang dengan menggunakan model Sinektik dan yang menggunakan model Consept Sentence Modification kemampuannya sedang. Sebab setelah dianalisis dan dihitung, hasil belajar siswa yang menulis guguritan maskumambang dengan menggunakan model Sinektik rata-ratanya adalah 78 dan 
90 | LOKABASA Vol. 6, No. 1, April 2015

yang menggunakan model Consept yang terendah baik siswa yang Sentence Modification rata-ratanya adalah menggunakan model sinektik maupun 75,6. Dalam aspek ini rata-rata siswa hanya siswa yang menggunakan model Consept memperhatikan jumlah baris dalam tiap bait tanpa memperhatikan watak pupuh dan jumlah engang (potongan kata). Akibatnya rata-rata nilai pada aspek ini merupakan Sentence Modification.

Contoh tulisan siswa yang menggunakan model Sinektik:

Pupuh : Maskumambang

Patokan : 12i-6a-8i-8a

Watak : nalangsa, nyeri, ceurik, prihatin

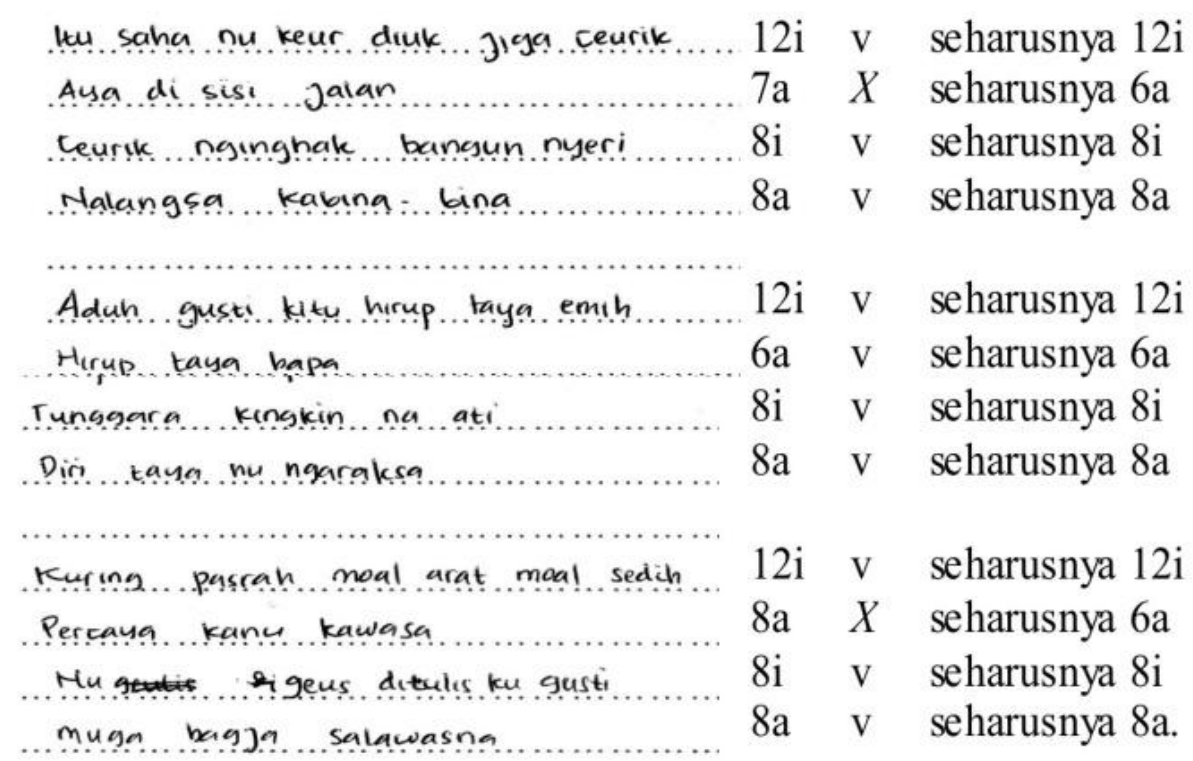

Keterangan: $\sqrt{ }=$ benar

$X=$ salah

Contoh tulisan siswa yang menggunakan model Consept Sentence Modification:

Pupuh : Maskumambang

Patokan : 12i-6a-8i-8a

Watak : nalangsa, nyeri, ceurik, prihatin 


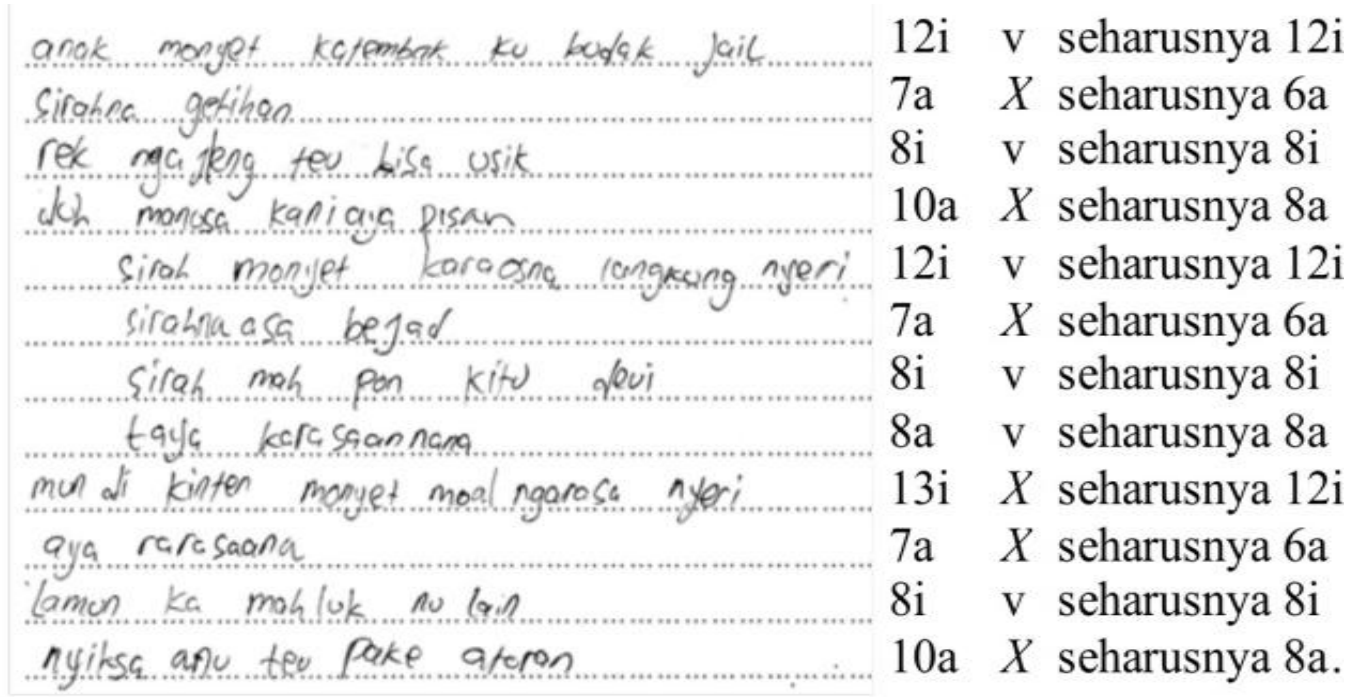

Keterangan: $\sqrt{ }=$ benar

$$
X=\text { salah }
$$

Selanjutnya menguji evektivitas hasil belajar menulis guguritan maskumambang yang menggunakan model Sinektik dan yang menggunakan model Consept Sentence Modification melalui uji sipat data dan uji hipotesis.

Hasil uji sipat data mengenai hasil belajar menulis guguritan maskumambang yang menggunakan model Sinektik dan yang menggunakan model Consept Sentence Modification, data nya normal dengan taraf kepercayaan 99\%. Hasil belajar menulis guguritan maskumambang yang menggunakan model Sinektik $\mathrm{X}_{\text {hitung }}=$ $7,47<X_{\text {tabel }}^{2}=11,3$. Begitu juga Hasil belajar menulis guguritan maskumambang yang menggunakan model Consept Sentence Modification $\mathrm{X}_{\text {hitung }}^{2}=9,82<$ $\mathrm{X}_{\text {tabel }}^{2}=11,3$. Selain normal, data hasil belajar menulis guguritan maskumambang yang menggunakan model Sinektik dan yang menggunakan model Consept Sentence Modification juga homogen sebab $\mathrm{F}_{\text {hitung }}=1,09<\mathrm{F}_{\text {tabél }}=1,90$. Setelah itu dilaksanakan uji hipotesis menggunakan uji $\mathrm{t}$ dan hasilnya $\mathrm{t}_{\mathrm{itung}}=1,830>\mathrm{t}_{\text {tabél }}=1,673$. Artinya pada taraf kepercayaan $\alpha=0,05$ hipotesis dalam penelitian ini ditolak. Hal ini membuktikan bahwa tidak ada perbedaan yang signifikan antara hasil belajar menulis guguritan maskumambang yang menggunakan model Sinektik dan yang menggunakan model Consept Sentence Modification.

\section{SIMPULAN}

Berdasarkan hasil analisis data maka disimpulkan bahwa: 1) hasil belajar menulis guguritan Maskumambang yang menggunakan model Sinektik memiliki ratarata nilai 80 ; 2) hasil belajar menulis guguritan Maskumambang yang menggunakan model Consept Sentence Modification memiliki rata-rata nilai 78,5 ; dan 3) uji sipat data mengenai hasil belajar menulis guguritan maskumambang yang menggunakan model Sinektik dan yang menggunakan model Consept Sentence Modification, data nya normal dengan taraf kepercayaan 99\%. Hasil belajar menulis guguritan maskumambang yang menggunakan model Sinektik $\mathrm{X}^{2}{ }_{\text {hitung }}=7,47$ $<\mathrm{X}_{\text {tabel }}^{2}=11,3$. Begitu juga Hasil belajar menulis guguritan maskumambang yang menggunakan model Consept Sentence Modification $\mathrm{X}^{2}$ hitung $=9,82<\mathrm{X}_{\text {tabel }}^{2}=11,3$. Selain normal, data hasil belajar menulis guguritan maskumambang yang menggunakan model Sinektik dan yang menggunakan model Consept Sentence 
Modification juga homogen sebab $\mathrm{F}_{\text {hitung }}=$ $1,09<\mathrm{F}_{\text {tabél }}=1,90$. Setelah itu dilaksanakan uji hipotesis menggunakan uji $t$ dan hasilnya $t_{\text {itung }}=1,830>t_{\text {tabél }}=1,673$. Artinya pada taraf kepercayaan $\alpha=0,05$ hipotesis dalam penelitian ini ditolak. Hal ini membuktikan bahwa tidak ada perbedaan yang signifikan antara hasil belajar menulis guguritan maskumambang yang menggunakan model Sinektik dan yang menggunakan model Consept Sentence Modification.

\section{PUSTAKA RUJUKAN}

Arikunto, Suharsimi. 2009. Metode Penelitian. Jakarta: Rineka Cipta.

Dinas Pendidikan Provinsi Jawa Barat. 2007. Standar Kompetensi dan Kompetensi Dasar Mata Pelajaran Bahasa dan Sastra Sunda. Dinas Pendidikan Provinsi Jawa Barat.

Joyce, Bruce \& Weil. 1980. Model Of Teaching. New Jersey: Prentice Hall, Inc

Rahman. 2007. Model Mengajar \& Bahan Pembelajaran. Jatinangor: Alqa Prisma Interdelta.
Rusyana Yus, Ami. 1980. Puisi Guguritan Sunda. Jakarta: Depdikbud.

Sugiyono. 2013. Metode Penelitian Kuantitatif Kualitatif. Bandung: Alfabeta.

Syaodih, Nana. 2005. Metode Penelitian Pendidikan. Bandung: Remaja Rosdakarya.

Tarigan, Henry Guntur. 2008. Menulis Sebagai Keterampilan Berbahasa. Bandung: Angkasa.

Wellek Rene, Warren. 2004. Teori Kesusastraan (terjemahan Melani Budianta). Yogyakarta: Unit Penerbitan Sastra Asia Barat Fakultas Ilmu Budaya UGM.

\section{UCAPAN TERIMA KASIH}

Peneliti mengucapkan terima kasih kepada semua pihak yang telah membantu selama pelaksanaan penelitian ini. Terima kasih pula kepada pihak pengelola jurnal yang telah menerbitkan artikel hasil penelitian ini. Semoga hasil penelitian ini bermanfaat bagi pendidikan. 